\title{
Staphylococcal slime layers and biofilm from different origins
}

\author{
Rodrigo Casquero Cunha ${ }^{1}$ (i) Michelle Dias Hornes da Rosa ${ }^{1}$ Cleomar da Silva ${ }^{1}$ \\ Francisco Denis Souza Santos ${ }^{1}$ (D) Fábio Pereira Leivas Leite ${ }^{1^{*}}$ (D)
}

\begin{abstract}
${ }^{1}$ Laboratório de Microbiologia, Núcleo de Biotecnologia, Centro de Desenvolvimento Tecnológico (CDTec), Universidade Federal de Pelotas (UFPEL), 96160-000, Capão do Leão, RS, Brasil. E-mail: Fabio_leite@ufpel.edu.br. ${ }^{*}$ Corresponding author.
\end{abstract}

\begin{abstract}
The genus Staphylococcus comprises some of the most important pathogenic bacteria for both humans and animals. It is responsible for bovine mastitis and canine otitis, besides being present in the microbiota of animals and as a contaminant in food. Its pathogenesis is related to the formation of capsule and biofilm, which contribute to its infectivity. The objective of this study was to observe the production of slime layer and formation of biofilm, which are related to the resistance to antimicrobial agents and presence of icaA and icaD genes, in 41 isolates of Staphylococcus spp. from different origins, provided by the Universidade Federal de Pelotas (UFPEL), Laboratório Regional de Diagnóstico (LRD). Strains of Staphylococcus spp. were cultivated in Congo red agar for capsule detection. Biofilm formation was detected using the 96-well microplate testing. Antimicrobial susceptibility testing was performed using the plate diffusion method. Part of the analyzed samples produced slime layer (36.6\%) and formed biofilm (17.1\%). However, six of those that formed biofilms were susceptible to the eight antibiotics tested in the antibiogram. In tests to determine the minimum bactericidal and inhibitory concentrations, gentamicin resistance of biofilm-forming strains was greater than that of non-forming strains. Ampicillin was the least effective antimicrobial drug (51\%), followed by tetracycline (71\%), neomycin (73\%), and erythromycin (73\%). Some isolates presented the icaA (6) and icaD (11) genes. Therefore, we suggested that the origin of an isolate can determine its expression of virulence factor and resistance to certain antibiotics.
\end{abstract}

Key words: Staphylococcus, biofilm, slime layer.

Slime layer e biofilme de Staphylococcus de diferentes origens

RESUMO: O gênero Staphylococcus abrange algumas das bactérias patogênicas mais importantes tanto para humanos como para animais. Ele é responsável pela mastite bovina e otite canina, além de estar presente na microbiota de animais e como contaminante em alimentos. Sua patogênese está relacionada à formação de cápsula e biofilme, que contribuem para sua infectividade. O objetivo deste estudo foi observar a produção de slime layer e a formação de biofilme, que estão relacionados à resistência a antibicrobianos e à presença dos genes icaA e icaD, em 41 isolados de Staphylococcus spp. de diferentes origens fornecidos pelo Laboratório Regional de Diagnóstico (LRD) da Universidade Federal de Pelotas (UFPEL). Os isolados de Staphylococcus spp. foram cultivados em ágar vermelho do Congo para detecção de cápsulas. A formação de biofilme foi detectada usando o teste de microplaca com 96 poços. O teste de susceptibilidade antimicrobiana foi realizado usando o método de difusão em placa. Parte das amostras analisadas produziram slime layer (36,6\%) e formaram biofilme (17,1\%). Entretanto, seis daquelas que formaram biofilmes foram sensiveis aos oito antibióticos testados no antibiograma. Em testes para determinar as concentrações bactericidas e inibitórias mínimas, a resistência à gentamicina de cepas formadoras de biofilme foi maior que aquela das cepas não formadoras. O antimicrobiano menos eficaz foi a ampicilina (51\%), seguida por tetraciclina (71\%), neomicina (73\%) e eritromicina (73\%). Alguns isolados apresentaram os genes icaA (6) e icaD (11). Portanto, sugerimos que a origem de um isolado pode determinar sua expressão de fator de virulência e resistência a certos antibióticos.

Palavras-chave: Staphylococcu, biofilme, slime layer.

\section{INTRODUCTION}

Staphylococcus is a genus of Grampositive bacteria associated with infection in animals and contamination of food. Species belonging to this genus often present some of the most important virulence factors such as formation of slime layers and biofilms (GÖTZ, 2002).

Slime layer (SL) is the name for the pseudo-capsule formed by Staphylococci, which is primarily composed of polysaccharides (HEILMANN et al., 1996). In S. epidermidis and $S$. aureus, these substances are regulated by the ica operon, which controls polysaccharide intercellular adhesins (PIA) (HEILMANN et al., 1996). PIApositive and -negative strains can be differentiated by cultivation in Congo red agar (HEILMANN \& GÖTZ, 1998). In Staphylococcus spp., production of PIA is a consequence of ica operon encoding, which is composed of four structural genes (icaA, icaB, icaC, 
and icaD). Expression of this operon is regulated by the icaR gene, which precedes the IcaA gene, and SL production is directly influenced by IcaA (GERKE et al., 1998; ROHDE et al., 2010). This gene encodes the enzyme $N$-acetylglucosaminyltransferase, which uses $\mathrm{N}$-acetylglucosamine as substrate. Expression of the icaD gene results in a protein that acts as a chaperone and correctly position IcaA on the membrane, thus increasing its activity.

Biofilm is defined as a structure composed of microorganism aggregates. They are surrounded by an extracellular matrix containing polymeric exopolysaccharides that adhere to a solid surface (SHIRTLIFF et al., 2002). Pores and small canals are reported in its highly hydrated structure (SHIRTLIFF et al., 2002). Such biofilms present protective functions against dehydration, bacteriophage infection, and antimicrobial agents (GILBERT et al., 2003). Bacterial biofilms are a major concern to the food industry for their potential to resist to antimicrobial treatments, facilitating pathogenic contamination and food degradation (ZOTTOLA \& SASAHARA, 1994). Biofilm is recognized as the primary mechanism involved in $S$. epidermidis infections (GILBERT et al., 2003), being associated with increased antibiotic resistance (GILBERT et al., 2003). The surface physicochemical characteristics are the main factors related to biofilm formation and expression of microorganism virulence factors such as production of exo-polymeric capsule and fimbriae and synthesis of adhesin (GILBERT et al., 2003).

We hypothesized that ica operon genes control the production/formation of SL in different species of Staphylococcus spp., and their susceptibility to antimicrobials is affected by presence of SL and biofilm. Therefore, the objectives of this study were to describe Staphylococcus spp. resistance to antimicrobial agents in the presence of SL and biofilm and detect the presence of genes related to SL expression in isolates provided by the Laboratório Regional de Diagnóstico (LRD), Universidade Federal de Pelotas (UFPel; RS).

\section{MATERIALS AND METHODS}

\section{Origin of samples}

Samples ( $\mathrm{n}=41)$ of Staphylococcus spp. of different origins provided by the LRD/UFPel were previously characterized as coagulase-positive or -negative and classified into species when possible. In this study, isolates from canine otitis (8), dog skin microbiota (15), pig exudative epidermitis (4), bovine mastitis (6), industrialized cheese (4), and pizza pieces (4) were used. Strains of S. aureus FDA (Food and Drug Administration) and ATCC (American Type Culture Collection) 25923 (icaA +/icaD +/Biofilm+/ $\mathrm{SL}+$ ) were used as controls in all assays.

\section{Cultivation and characterization}

The samples were cultivated by dilution in Petri plates containing tryptic soy agar (TSA; DIFCO). Three isolated colonies from each sample were used for hemolysis tests on sheep blood agar $(8 \%)$ to confirm hemolytic activity by synthesis of $\alpha$ and $\beta$ - hemolysin. Three colonies isolated from each sample were inoculated in liquid tryptic soy broth (TSB; DIFCO) medium, and the following tests were performed with these crops: SL production, biofilm formation, antimicrobial susceptibility, minimum inhibitory and bactericidal concentrations, and DNA extraction.

Slime layer: Slime layer was detected by the Congo red agar (CRA) inoculation method, using Brain Heart Infusion broth (BHI; $37 \mathrm{~g} / \mathrm{L}$; Oxoid), sucrose (50 g/L; Oxoid), agar (15 g/L; Oxoid), and Congo red ( $0.8 \mathrm{~g} / \mathrm{L}$; BDH Ltd), as described by (GILBERT et al., 2003). Formation of dark and wrinkly colonies was considered positive for production of SL (Figure 1).

Biofilms: The culture concentrations in TSB (incubation: $24 \mathrm{~h}$ ) were standardized by spectrophotometry (absorbance at $600 \mathrm{~nm}$, A600nm, $=0.7)$. Subsequently, dilutions (1:40) of cultures in TSB medium were prepared and supplemented with glucose $(0.25 \%)$ solution. After standardization, each sample, as well as the control (ATCC and FDA) strains, were added to 96-well U-bottom microplates ( $200 \mu \mathrm{L} /$ well, triplicate), and were incubated $\left(37^{\circ} \mathrm{C}\right.$; $24 \mathrm{~h}$ ). Plates were then washed (three times) with phosphate-buffered saline (PBS; $137 \mathrm{mM} \mathrm{NaCl}$, $2.7 \mathrm{mM} \mathrm{KCl}$, and $10 \mathrm{mM}$ phosphate buffer, $\mathrm{pH}$ 7.4) and allowed to dry at room temperature (RT). Crystal violet solution (200 $\mu \mathrm{L} /$ well) was added and the plates were again incubated (RT; $15 \mathrm{~min}$ ). After staining, each plate was washed (three times) with distilled water $(200 \mu \mathrm{L} /$ well $)$ and allowed to dry (RT; $20 \mathrm{~min}$ ). Absorbance (540-nm filter) of the stained plates was read in a microplate reader (BioRad xMarkTM). Samples that showed an absorbance $\geq 1.0$ were considered biofilm forming (GILBERT et al., 2003).

Antimicrobial susceptibility test: Samples were submitted to antimicrobial susceptibility testing according to the plate diffusion technique as recommended by the Clinical and Laboratory Standards Institute (CLSI, 2016). Gentamicin (10 $\mu \mathrm{g})$, 


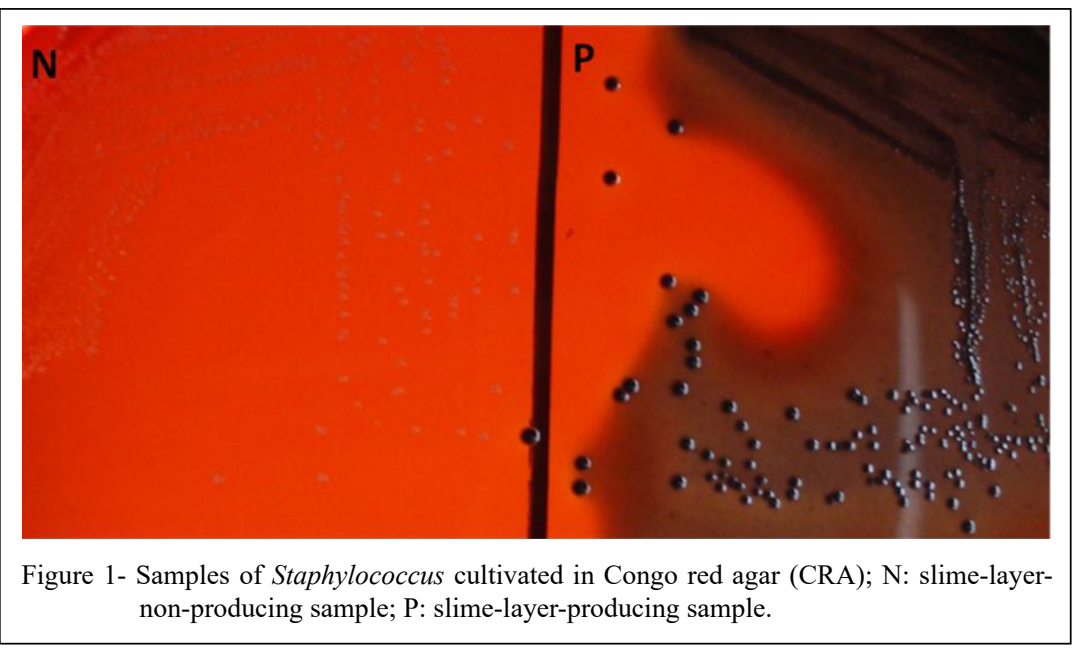

neomycin $(30 \mu \mathrm{g})$, novobiocin $(5 \mu \mathrm{g})$, erythromycin $(15 \mu \mathrm{g})$, ampicillin $(10 \mu \mathrm{g})$, nitrofurantoin $(300 \mu \mathrm{g})$, tetracycline $(30 \mathrm{~g})$, and chloramphenicol (30 $\mu \mathrm{g}$; Laborclin) were the antimicrobials used in this study.

Minimum inhibitory concentration (MIC):

The MIC was tested using four biofilm-forming samples, and four non-biofilm-forming samples. The MIC was determined according to the CLSI (2016) and ANVISA (2003). Four commonly used antibiotics available in our laboratory were tested for the MIC: ampicillin $(1.0 \mu \mathrm{g} / \mu \mathrm{L})$, gentamicin $(0.5 \mu \mathrm{g} /$ $\mu \mathrm{L})$, kanamycin $(0.5 \mu \mathrm{g} / \mu \mathrm{L})$, and chloramphenicol $(0.5 \mu \mathrm{g} / \mu \mathrm{L})$. The antibiotics were serially diluted (base 2) in microplates containing Lúria Bertani (LB) medium. Each well of the plate was inoculated (in triplicate) with the standardized cultivation (A600nm $=0.7 ; 5 \mu \mathrm{L})$ and LB was inoculated without antibiotic (control) and the plates were incubated $\left(37^{\circ} \mathrm{C}\right.$; overnight). The MIC was determined colorimetrically using 2,3,5-triphenyl tetrazolium chloride to dye the wells containing live cells.

Minimum Bactericidal Concentration (MBC): The antibiotic bactericidal activity was tested sowing the cultivation $(5 \mu \mathrm{L})$ from each microtiter plate, where cellular activity was not detected using the tetrazolium salt in TSA. The MBC was indicated by the dilution prior to that in which bacterial growth was observed in TSA (CLSI, 2016).

Minimum bactericidal concentrations after biofilm formation (MBCB): Procedure used to determine the MBCB was the same used in the MIC method, but antibiotics were inoculated $24 \mathrm{~h}$ after biofilm formation. The MBCB was performed according to the method used in the MBC tests (CLSI, 2016).

\section{$D N A$ extraction and icaA and icaD $P C R$}

The extraction protocol began with separation of TSB cultivation $(1 \mathrm{~mL})$ from each isolate in $1.5-\mathrm{mL}$ microtubes, being then centrifuged (13,000 rpm; $5 \mathrm{~min})$. The supernatant was discarded, and the pellet was suspended in STES buffer $(150 \mu \mathrm{L}$; $200 \mathrm{mM}$ Tris- $\mathrm{HCl}, 500 \mathrm{mM} \mathrm{NaCl}$, SDS $0.1 \%(\mathrm{~m} / \mathrm{v})$, $10 \mathrm{mM}$ EDTA, pH 7.6). Then, glass pearls $(50 \mu \mathrm{L})$ were added together with phenol:chloroform:isoamyl alcohol $(12: 12: 1)$ solution $(150 \mu \mathrm{L})$, and vortexed (1 min). The sample was then centrifuged $(13,000 \mathrm{~g} ; 5$ min), the supernatant was collected, and the pellet was discarded. For DNA precipitation, absolute ethanol (2 vol.) and sodium acetate (3.0 M; 0.1 vol.) were added to the supernatant. Solution was homogenized by inversion and stored in the freezer $\left(-70^{\circ} \mathrm{C} ; 30 \mathrm{~min}\right)$. Samples were then centrifuged $(13,000 \mathrm{~g} ; 20 \mathrm{~min})$ and the established DNA was washed with ethanol $(70 \%)$ and left to dry (RT; $15 \mathrm{~min})$. The dried DNA was diluted in $45 \mu \mathrm{L}$ of elution buffer (TE; $100 \mathrm{mM}$ Tris- $\mathrm{HCl}$, and $10 \mathrm{mM}$ EDTA, $\mathrm{pH} 8.0$ ), and stored in the freezer $\left(-20^{\circ} \mathrm{C}\right)$.

The total DNA extracted from each sample was quantified in a GE Healthcare NanoVue Plus ${ }^{\mathrm{TM}}$ spectrophotometer, analyzed in an electrophoresis equipment in agarose gel $(0.8 \%)$ and stored $\left(-20{ }^{\circ} \mathrm{C}\right)$ for later use.

Before amplification of the icaA and icaD genes, the DNA of a portion of the $16 \mathrm{~S}$ region was submitted to PCR. To determine the presence of the icaA and icaD genes, PCR gene amplification was performed using specific primers (Table 1) for each gene (VASUDEVAN et al., 2003). Amplifications were performed in a thermocycler (GeneAmp PCR System 2400), in solutions ( $25 \mu \mathrm{L})$ containing DNA $(20 \mathrm{ng} ; 1 \mu \mathrm{L})$, the respective oligonucleotides $(0.4$ pmol; $1 \mu \mathrm{L}$ ), Taq DNA Polymerase (1 U; $0.2 \mu \mathrm{L}$; 
Table 1 - Sequences of primers used to amplify the icaA and icaD genes.

\begin{tabular}{lcc}
\hline Primers & Sequences & Target Genes \\
\hline IcaA -For & - CCTAACTAACGAAAGGTAG 5' - 3 & IcaA \\
\hline IcaA -Rev & - AAGATATAGCGATAAGTGC 5' - 3' & IcaA \\
IcaD-For & - ATGGTCAAGCCCAGACAGAG 5' - 3' & IcaD \\
IcaD-Rev & - CGTGTTTCAACATTTAATGCAA 5' - 3' & IcaD \\
\hline
\end{tabular}

Reference: VASUDEVAN et al. (2003).

Invitrogen TM), dNTPs $(2 \mathrm{mM} ; 1 \mu \mathrm{L})$, reaction buffer $(5 \mu \mathrm{L} ; 5 \times)$, and sterile distilled water $(15.8$ $\mu \mathrm{L})$. Reactions for amplification of the icaA and icaD genes were performed with similar thermocycling steps: incubation at $94{ }^{\circ} \mathrm{C}(5 \mathrm{~min})$ followed by 35 cycles at $94{ }^{\circ} \mathrm{C}(30 \mathrm{~s}), 55^{\circ} \mathrm{C}(1 \mathrm{~min}), 72{ }^{\circ} \mathrm{C}(90 \mathrm{~s}$ for icaA and $30 \mathrm{~s}$ for icaD), and an end cycle of $72{ }^{\circ} \mathrm{C}$ (1 min). In each thermal cycling, a reaction with TE was done instead with DNA to serve as a negative reaction control. All isolates were submitted to DNA extraction and PCR.

After amplification, the reaction solution $(12 \mu \mathrm{L})$ was subjected to electrophoretic analyses in agarose gel $(1 \%)$ in TBE buffer $(45 \mathrm{mM}$ Tris-borate and $1 \mathrm{mM}$ EDTA; $\mathrm{pH}$ 8.0) and stained with ethidium bromide. The molecular weight marker Plus $1 \mathrm{~kb}$ DNA ladder (InvitrogenTM) was used to estimate the molecular weights of the PCR products. The agarose gels were illuminated with UV light and photographed in a trans-illuminator appliance. Amplification of the $i c a A$ and $i c a D$ genes generated the products with $1,315 \mathrm{bp}$ and $381 \mathrm{bp}$, respectively.

Statistical analysis: Statistical analyses were performed using the MedCalc 8.0.0.0 software.
One-factor ANOVA was used for analysis of variance of results of the antimicrobial resistance tests, and Kruskal-Wallis was used for analyses of frequency distributions of the non-parametric characters evaluated. The significance level was established at $p<0.05$. All tests were performed in triplicate.

\section{RESULTS}

Samples isolated from different origins were used in this study: canine otitis (8), dog skin microbiota (15), pig exudative epidermitis (4), bovine mastitis (6), industrialized cheese (4), and pizza pieces (4). Of the total number of samples, 15 showed to be SL-producing and 7 were biofilm-forming.

Of the 15 isolated SL producers, 11 presented no biofilm formation. Among these, the three isolates from a piece of pizza (the only $S$. aureus isolated and shown to be susceptible in the antibiogram), revealed that controlling these isolates is possible when the 8 antibiotics are used (Table 2). Table 3 shows results from the antimicrobial susceptibility testing performed with different isolates against 8 antimicrobial agents.

Table 2 - Number of isolates in relation to "slime layer", biofilms, and PCR for the icaA and icaD genes.

\begin{tabular}{|c|c|c|c|c|c|c|c|}
\hline \multirow[t]{2}{*}{ Samples } & \multicolumn{2}{|c|}{------PCR------ } & \multicolumn{4}{|c|}{-----------------------Phenotipes--------------------- } & \multirow[t]{2}{*}{ Total of samples } \\
\hline & $i c a \mathrm{~A}$ & $i c a \mathrm{D}$ & $\mathrm{SL}+\mathrm{B}+$ & $\mathrm{SL}+\mathrm{B}-$ & SL- B- & SL- B+ & \\
\hline S. aureus (Dog Otitis) & 1 & 4 & 0 & 8 & 0 & 0 & 8 \\
\hline S. aureus (Dog Skin) & 3 & 3 & 0 & 0 & 12 & 0 & 12 \\
\hline S. aureus (Pizza) & 0 & 0 & 0 & 3 & 1 & 0 & 4 \\
\hline S. aureus (Cheese) & 2 & 3 & 4 & 0 & 0 & 0 & 4 \\
\hline S. epidermidis (Bovine Mastitis). & 0 & 0 & 0 & 0 & 6 & 0 & 6 \\
\hline S. hyicus (Pig) & 0 & 1 & 0 & 0 & 1 & 3 & 4 \\
\hline S. intermedius (Dog Skin) & 0 & 0 & 0 & 0 & 3 & 0 & 3 \\
\hline TOTAL & & & 4 & 11 & 23 & 3 & 41 \\
\hline
\end{tabular}

SL+: slime-layer producing; SL-: slime-layer non-producing; B+: biofilm forming; B-: biofilm non-forming. 
Table 3. Number of isolates resistant and susceptible to the antimicrobials tested.

\begin{tabular}{|c|c|c|c|c|c|c|c|c|c|c|c|c|c|c|c|c|}
\hline \multirow[t]{2}{*}{ Samples } & \multicolumn{2}{|c|}{ Gen } & \multicolumn{2}{|c|}{ Neo } & \multicolumn{2}{|c|}{ Nov } & \multicolumn{2}{|c|}{ Tetr } & \multicolumn{2}{|c|}{ Chlor } & \multicolumn{2}{|c|}{ Amp } & \multicolumn{2}{|c|}{ Eryth } & \multicolumn{2}{|c|}{ Nitr } \\
\hline & $\mathrm{R}$ & $\mathrm{S}$ & $\mathrm{R}$ & $\mathrm{S}$ & $\mathrm{R}$ & $\mathrm{S}$ & $\mathrm{R}$ & $\mathrm{S}$ & $\mathrm{R}$ & $\mathrm{S}$ & $\mathrm{R}$ & $\mathrm{S}$ & $\mathrm{R}$ & $\mathrm{S}$ & $\mathrm{R}$ & $\mathrm{S}$ \\
\hline S. aureus (Dog Otitis) & 0 & 8 & 4 & 4 & 4 & 4 & 2 & 6 & 0 & 8 & 6 & 2 & 3 & 5 & 0 & 8 \\
\hline S. aureus (Dog Skin) & 1 & 11 & 2 & 10 & 0 & 12 & 8 & 4 & 1 & 11 & 7 & 5 & 2 & 10 & 1 & 11 \\
\hline S. aureus (Pizza) & 1 & 3 & 0 & 4 & 1 & 3 & 0 & 4 & 0 & 4 & 1 & 3 & 0 & 4 & 0 & 4 \\
\hline S. aureus (Cheese) & 0 & 4 & 0 & 4 & 0 & 4 & 0 & 4 & 0 & 4 & 0 & 4 & 0 & 4 & 0 & 4 \\
\hline S. epidermidis (Bovine Mastitis). & 1 & 5 & 5 & 1 & 0 & 6 & 1 & 5 & 1 & 5 & 6 & 0 & 6 & 0 & 0 & 6 \\
\hline S. hyicus (Pig ) & 0 & 4 & 0 & 4 & 0 & 4 & 1 & 3 & 0 & 4 & 0 & 4 & 0 & 4 & 0 & 4 \\
\hline S. Intermedius (Dog) & 0 & 3 & 0 & 3 & 0 & 3 & 0 & 3 & 0 & 3 & 0 & 3 & 0 & 3 & 0 & 3 \\
\hline TOTAL & 3 & 38 & 11 & 30 & 5 & 36 & 12 & 29 & 2 & 39 & 20 & 21 & 11 & 30 & 1 & 40 \\
\hline
\end{tabular}

R: resistant; S: susceptible; GEN: gentamicin (10 $\mu \mathrm{g})$; NEO: neomycin $(30 \mu \mathrm{g})$; NOV: novobiocin $(5 \mu \mathrm{g})$; ERYTH: erythromycin $(15 \mu \mathrm{g})$; AMP: ampicillin $(10 \mu \mathrm{g})$; NITR: nitrofurantoin $(300 \mu \mathrm{g})$; TETR: tetracycline $(30 \mathrm{~g})$; CHLOR: chloramphenicol (30 $\mu \mathrm{g}$;).

When the samples were compared with regard to their origin, those of animal origin $(29 / 33 ; 87.9 \%)$ showed more resistance to the antimicrobials than those of food origin $(1 / 8 ; 12.5 \%)(\mathrm{p}<0.05)$.

With regard to testing for MIC, MBC, and MBCB (table 4), the only significant difference was observed among biofilm-forming isolates, which showed to be more resistant to gentamicin than to biofilm non-forming isolates. Staphylococcus aureus isolated from dog skin showed to be highly resistant to ampicillin $(2 \mu \mathrm{g} / \mu \mathrm{L})$ after biofilm formation and in the antibiogram.

Only part of the isolates submitted to PCR presented the icaA (6) and acaD (11) genes. Both genes were detected in 2 isolates from slime layer producing bacteria. However, a low relationship between isolates and genes was reported (chi-square test; $\mathrm{p}=0.910$ ). Staphylococcus aureus was isolated from canine otitis and cheese, which presented biofilm formation. The 6 S. aureus isolates containing

Table 4 - Data (in $\mu \mathrm{g} / \mu \mathrm{L}$ ) related to minimum inhibitory concentration (MIC), minimum bactericidal concentration (MBC), and minimum bactericidal concentrations after biofilm formation (MBCB) testings.

\begin{tabular}{|c|c|c|c|c|c|c|c|c|c|c|c|c|}
\hline \multirow[t]{2}{*}{ Samples } & \multicolumn{3}{|c|}{ Gentamicin } & \multicolumn{3}{|c|}{ Kanamycin } & \multicolumn{3}{|c|}{ Ampicillin } & \multicolumn{3}{|c|}{ Chloramphenicol } \\
\hline & MIC & $\mathrm{MBC}$ & MBCB & MIC & $\mathrm{MBC}$ & MBCB & MIC & $\mathrm{MBC}$ & MBCB & MIC & $\mathrm{MBC}$ & MBCB \\
\hline S. aureus (Cheese) ${ }^{\mathrm{a}}$ & 0.0078 & 0.0625 & 1 & 0.0313 & 0.25 & 1 & 0.0002 & 0.002 & 0.0039 & 0.0039 & 0.0625 & 0.125 \\
\hline S. aureus (Cheese) ${ }^{\mathrm{a}}$ & 0.0078 & 0.0313 & 0.5 & 0.0156 & 0.125 & 1 & 0.0002 & 0.0039 & 0.0039 & 0.0039 & 0.0625 & 0.25 \\
\hline S. aureus (Cheese) ${ }^{\mathrm{a}}$ & 0.0039 & 0.0078 & 1 & 0.0313 & 0.5 & 1 & 0.0002 & 0.002 & 0.0039 & 0.0039 & 0.0625 & 0.0625 \\
\hline S. aureus (Cheese) ${ }^{\mathrm{a}}$ & 0.0078 & 0.0156 & 1 & 0.0313 & 0.125 & 1 & 0.0002 & 0.0039 & 0.0039 & 0.0156 & 0.0625 & 0.125 \\
\hline S. aureus (ATCC) ${ }^{\mathrm{b}}$ & 0.0156 & 0.0313 & 0.5 & 0.0625 & 0.5 & 1 & 0.0002 & 0.0078 & 0.0039 & 0.0078 & 0.0625 & 0.25 \\
\hline $\begin{array}{l}\text { S. aureus } \\
\text { (Dog Skin) }^{\mathrm{b}}\end{array}$ & 0.0078 & 0.125 & 0.125 & 0.0156 & 0.125 & 0.5 & 0.0313 & 0.0039 & 2 & 0.0156 & 0.0078 & 0.125 \\
\hline $\begin{array}{l}\text { S. aureus } \\
\text { (Dog Skin) }^{\text {b }}\end{array}$ & 0.0156 & 0.125 & 0.5 & 0.0156 & 0.25 & 1 & 0.0002 & 0.0156 & 0.0039 & 0.0156 & 0.0625 & 0.0625 \\
\hline $\begin{array}{l}\text { S. aureus } \\
\text { (Dog Skin) }^{\mathrm{b}}\end{array}$ & 0.0039 & 0.0313 & 0.25 & 0.0156 & 0.25 & 1 & 0.0002 & 0.0156 & 0.0039 & 0.0156 & 0.0625 & 0.0625 \\
\hline $\begin{array}{l}\text { One-way ANOVA } \\
\text { (p values) }\end{array}$ & 0.253 & 0.150 & 0.014 & 0.997 & 0.801 & 0.356 & 0.356 & 0.40 & 0.356 & 0.100 & 0.356 & 0.801 \\
\hline
\end{tabular}

a: slime-layer and biofilm-producing samples; b: biofilm non-forming samples; ATCC: American Type Culture Collection. 
the icaA gene were isolated from dog skin (3), cheese (2), and canine otitis media (1). The eleven samples containing the $i c a D$ gene were $S$. aureus isolated from dog skin (3); S. hyicus (biofilm former) isolated from pig (1). Staphylococcus aureus were isolated from canine otitis (4) and cheese pieces (3). No significant difference between samples from food and clinical strains was reported (chi-square test; $\mathrm{p}=0.639$ ).

The IcaA and $i c a D$ genes were not detected in the $S$. epidermidis isolates from bovine mastitis (6) or $S$. intermedius isolates from dogs (3). These species also presented no SL production or biofilm formation. Of the four $S$. aureus samples isolated from pizza pieces, none presented the icaA and icaD genes. However, three of them were SL producers. The icaA and icaD genes were not detected in half of the S. aureus isolates from dog skin (6/12), and SL was not produced, and biofilm was not formed by this species. In the other half of dog skin isolates, the icaA (3) and icaD (3) genes were detected, but SL was not produced, and biofilm was not formed. One sample of $S$. hyicus presented the icaD gene, and most (3/4) isolates formed biofilm.

\section{DISCUSSION}

The observed distribution of the SLproducing samples contributes to the general consensus that coagulase-positive strains are more pathogenic, since SL production and biofilm formation are important virulence factors (GÖTZ, 2002). Analysis using the chi-square test $(P=0.41)$ indicated no significant expression of interrelationship between the SL and biofilm phenotypes.

All $S$. aureus cheese isolates were biofilm forming and SL producing, suggesting that these factors are important for its survival in production plants, thus favoring its presence during cheese processing. Conversely, $\mathrm{pH}$ affects the microorganism adhesion ability (GALINARI et al., 2014), and the rate of $S$. aureus adherence to a solid surface decreases in low $\mathrm{pH}$, as observed in some cheeses (ZMANTAR et al., 2010). Thus, other sources of cheese contamination are possible after manufacture, by detachment of biofilm remnants from either contaminated utensils, or workers' hands during manipulation.

The $S$. hyicus samples isolated from pigs were not SL producers; although, most of them (3/4; $75 \%$ ) presented biofilm formation. This suggested that biofilm formation in this species tends to be a determining factor in establishing infections, such as exudative epidermitis in pigs. This species is present in most pig farms. Its rate of isolation from pig skin is 5.2 times higher than that of $S$. aureus, and it presents high levels of resistance to antimicrobial agents (PARK et al., 2013). In isolates of S. hyicus, resistance to penicillin $\mathrm{G}(97.2 \%)$, ampicillin (97.2\%), tetracycline $(71.1 \%)$, and ceftiofur (55.6\%), in addition to other drugs was also reported (PARK et al., 2013).

Neither of the $S$. aureus (12) and $S$. intermedius (3) isolates from dog skin produced SL or formed biofilm, thus explaining their low pathogenicity (JUNCO \& BARRASA, 2002). Another finding that supports this hypothesis is that no biofilm was formed by $S$. aureus isolated from canine otitis media; although, all of them were SL producers. This suggested a higher pathogenicity for the strain, increasing resistance of bacteria and consequent recurrence of chronic otitis cases (OLIVEIRA et al., 2005). In another article, the author considers biofilm forming isolates presenting as black colonies in CRA, and reported the ability of $S$. intermedius isolates to form biofilms (11\%) (MOREIRA et al., 2012). In the present study, we considered these colonies as only SL producers; although, in such colonies a high rate of biofilm formation has already been reported (MOREIRA et al., 2012). Only isolates able to form biofilm on the surface of microtiter plate wells were considered biofilm-forming ones.

The $S$. epidermidis samples isolated from bovine mastitis neither produced SL nor formed biofilm, indicating that these factors are not responsible for or determinant of the occurrence of disease. However, it is known that the ability of $S$. epidermidis to form biofilms through ica gene expression is an important factor for the establishment of infections (GOMES et al., 2011; SOLATI et al., 2015).

Most of biofilm-forming samples (6/7; $85.7 \%$ ) were susceptible to the 8 antibiotics tested by antibiogram, but only $S$. hyicus showed resistance to tetracycline. It is known that this antibiotic (among others such as chloramphenicol and nitrofurantoin) has been used as a feed additive to promote growth in pigs. This practice is currently prohibited due to restrictions in Europe. However, tetracycline is still used in Brazil, and such resistance may be the result of improper use of this antibiotic. Regarding the samples tested in this study, this information is important, because it highlighted that biofilm formation is not consistent with antimicrobial resistance, contradicting data already published (GILBERT et al., 2003). However, given that four of these samples were from cheese of industrial origin, and antimicrobials are not used during its processing, it can be expected that these strains showed no resistance to antibiotics, 
because they underwent no selection pressure. They are different from the strains isolated from animals, in which biofilms appear as a resistance factor against antibiotics (KNOBLOCH et al., 2002).

From the data presented in table 3 , we can infer that ampicillin was the least effective antibiotic, to which $48.8 \%(20 / 41)$ of the isolates were resistant. However, these isolates presented weak statistical differences $(\mathrm{p}=0.083)$ and decreasing resistance percentages of the isolates as compared to the second less effective antibiotic, tetracycline $(29.2 \%)$, which is the most used in the clinics for domestic animals, followed by neomycin (26.8\%) and erythromycin $(26.8 \%)$, which are also widely used in veterinary clinics. Perhaps, this is the reason for the noticeable bacterial resistance to these drugs. These were followed by Novobiocin $(12.2 \%)$. The most effective antibiotics against the samples and the corresponding resistance percentages of the isolates were as follows: nitrofurazone $(2.4 \%)$, gentamicin $(4.9 \%)$ and chloramphenicol $(4.9 \%)$. All samples of $S$. epidermidis isolated from dogs showed resistance to ampicillin and erythromycin, and only one showed no resistance to neomycin. These last few rates of resistance are probably due to inattentive use of these drugs in dog clinics.

The genus Staphylococcus is among the chief causes of bovine mastitis. Regarding this type of infection, $S$. aureus is the most frequently isolated species, being responsible for infections with high somatic cell counts in milk. The establishment of infections and contaminations by species belonging to this genus is facilitated by the presence of virulence factors, which are of great importance for SL expression and biofilm formation (GÖTZ, 2002).

Staphylococcus hyicus sample isolated from pigs, in which the icaD gene was detected by PCR, was the only sample that did not belong to the $S$. aureus species. In addition, 75\% (3/4) of the $S$. hyicus isolated from pigs showed biofilm formation, and only $S$. hyicus and $S$. aureus showed biofilm formation.

The lower prevalence of the IcaA gene in relation to the $i c a D$ gene was already reported and was also observed in this study. Regarding SL producer isolates, a $53 \%$ rate for detection of the $i c a A$ and $i c a D$ genes was also reported (CIFTCI et al., 2009), whereas different rates were found for icaA $(27 \%)$ and icaD $(64.4 \%)$ in the present study.

In this study, the icaA (21\%) and icaD $(36 \%)$ genes were detected in isolates from $S$. aureus, and both genes were detected simultaneously in only $7.1 \%$ of these isolates. Prevalences of the icaA
$(20 \% ; 3 / 15)$ and icaD $(47 \% ; 7 / 15)$ genes were also calculated for isolates of SL producers.

The differences between gene prevalence in the phenotypes may be explained in the light of the diversity of material from which the isolates were obtained. In a previous study (ARCIOLA et al., 2001), an association test was performed for the icaA and icaD genes to phenotype, and part of $\mathrm{S}$. aureus isolates (61\%) harbored these genes. Another study (ROHDE et al., 2001) correlated SL producing samples with the presence of genes in few $(2.5 \%)$ isolates, whereas other authors (MELO et al., 2013) reported higher values $(50.0,37.5$, and $85.0 \%)$ for the isolates with correlated genes. When these values are analyzed, a great variation is seen in the ratios of genotypic to phenotypic tests. Thus, comparison between results obtained in this study and the literature is difficult. Thus, our data partly agreed with the literature. They do not allowed us to establish a relationship between the icaA and icaD genotypes and the phenotypic tests as performed for SL production and biofilm formation by the isolates reported herein.

In this study we were able to show that the susceptible SL-producing isolates exhibited a decreased susceptibility to gentamicin after biofilm formation. In addition, correlation between resistance to antimicrobial agents and phenotypic factors of SL production and biofilm formation was not found. Furthermore, genotypic markers were not evaluated here.

High levels of antimicrobial resistance were not observed with the isolates presented here, but different behaviors occurred depending on the isolates and their origins. However, it is known that microbial resistance is a growing problem and future perspectives for the use of antimicrobial drugs have become uncertain. Thus, controlling the use of antibiotics, especially in veterinary medicine, is necessary to combat this problem. Moreover, development of research to better understand the genetic mechanisms of microbial resistance and continuation of studies in the search for new synthetic and natural drugs are essential.

\section{CONCLUSION}

The importance of this study is in its evaluation of slime layer production and biofilm formation in isolates of different origins and correlation with antimicrobial resistance. The antibiotic bactericidal activity was tested sowing the cultivation $(5 \mu \mathrm{L})$ from each microtiter plate well where cellular activity was not detected using the 
tetrazolium salt in TSA. The MBC was indicated by the dilution prior to that in which bacterial growth was observed in TSA (CLSI, 2016). The findings indicated that slime layer production and biofilm formation are independent and may or may not occur simultaneously. We observed that the biofilm-forming isolates were susceptible to the antibiotics used in this study. Origin of the isolate, whether from animal or food, may influence bacterial resistance to antibiotics.

\section{DECLARATION OF CONFLICT OF INTERESTS}

The authors declare no conflict of interest. The founding sponsors had no role in the design of the study; in the collection, analyses, or interpretation of data; in the writing of the manuscript, and in the decision to publish the results.

\section{ACKNOWLEDGEMENTS}

The authors are grateful to Conselho Nacional de Desenvolvimento Científico e Tecnológico (CNPq), and the Coordenação de Aperfeiçoamento de Pessoal de Nível Superior (CAPES), Brasil, for granting scholarship.

\section{AUTHORS' CONTRIBUTIONS}

All authors contributed equally for the conception and writing of the manuscript. All authors critically revised the manuscript and approved of the final version.

\section{REFERENCES}

ANVISA, 2003. Padronização dos testes de sensibilidade a Antimicrobianos por Disco-difusão: Norma Aprovada - Oitava Edição, Clinical and Laboratory Standards Institute - CLSI. Available from: $<$ http://www.anvisa.gov.br/servicosaude/manuais/ clsi/clsi_OPASM2-A8.pdf>. Accessed: Apr. 10, 2018.

ARCIOLA, C.R., et al. Presence of icaA and icaD genes and slime production in a collection of staphylococcal strains from catheter-associated infections. J. Clin. Microbiol, v39, p. 2151-6, 2001. Available from: <https://doi.org/10.1128/JCM.39.6.21512156.2001>. Accessed: Apr. 10, 2018.

CIFTCI, A., et al. Detection of methicillin resistance and slime factor production of Staphylococcus aureus in bovine mastitis. Brazilian J. Microbiol, v.40, p. 254-261, 2009. Available from: $<$ https://doi.org/10.1590/S1517-83822009000200009>. Accessed: Apr. 10, 2018.

CLINICAL AND LABORATORY STANDARDS INSTITUTE, 2016. Performance standards for antimicrobial Susceptibility Testing. An informational supplement for global application developed through the Clinical and Laboratory Standards Institute. CLSI Doc. M100-S16CLSI, Wayne, PA. Available from: <https:// clsi.org/standards/products/microbiology/documents/m100-3/> Accessed: Apr. 10, 2018.

GALINARI, É., et al. Microbiological aspects of the biofilm on wooden utensils used to make a Brazilian artisanal cheese. Braz.
J. Microbiol, v.45, p.713-20, 2014. Available from: <http:// dx.doi.org/10.1590/S1517-83822014000200047>. Accessed: Apr. 10, 2018

GERKE, C., et al. Characterization of the $\mathrm{N}$-acetylglucosaminyltransferase activity involved in the biosynthesis of the Staphylococcus epidermidis polysaccharide intercellular adhesin. J. Biol. Chem. v.273, p. 18586-93, 1998. Available from: <https://doi.org/10.1074/JBC.273.29.18586>. Accessed: Apr. 10, 2018.

GILBERT, P., et al. Formation of microbial biofilm in hygienic situations: a problem of control. Int. Biodeterior. Biodegradation, v. 51,p. 245-248, 2003. Available from: < https://doi.org/10.1016/ S0964-8305(03)00043-X>. Accessed: Apr. 10, 2018.

GOMES, F., et al. Virulence Gene Expression by Staphylococcus epidermidis Biofilm Cells Exposed to Antibiotics. Microb. Drug Resist, v.17, p.191-196, 2011. Available from: <https://doi. org/10.1089/mdr.2010.0149>. Accessed: Apr. 10, 2018.

GÖTZ, F. Staphylococcus and biofilms. Mol. Microbiol, v. 43, p.1367-1378, 2002. Available from: <https://doi.org/10.1046 /j.1365-2958.2002.02827.x>. Accessed: Apr. 10, 2018.

HEILMANN, C., GÖTZ, F. Further Characterization of Staphylococcus epidermidis Transposon Mutants Deficient in Primary Attachment or Intercellular Adhesion. Zentralblatt für Bakteriol, v.287, p. 69-83, 1998. Available from: <https://doi. org/10.1016/S0934-8840(98)80149-7>. Accessed: Apr. 10, 2018.

HEILMANN, C., et al. Molecular basis of intercellular adhesion in the biofilm-forming Staphylococcus epidermidis. Mol. Microbiol, v.20, p. 1083-1091, 1996. Available from: $<$ https://doi. org/10.1111/j.1365-2958.1996.tb02548.x>. Accessed: Apr. 10, 2018.

KNOBLOCH, J., et al. Minimal attachment killing (MAK): a versatile method for susceptibility testing of attached biofilm-positive and -negative Staphylococcus epidermidis. Med. Microbiol. Immunol, v.191, p.107-114, 2002. Available from: <https://doi.org/10.1007/ s00430-002-0125-2>. Accessed: Apr. 10, 2018.

MELO, P. de C., et al. Comparison of methods for the detection of biofilm formation by Staphylococcus aureus isolated from bovine subclinical mastitis. Brazilian J. Microbiol, v.44, p.119124, 2013. Available from: <https://doi.org/10.1590/S151783822013005000031>. Accessed: Apr. 10, 2018.

MOREIRA, C.A., et al. Biofilm production by clinical staphylococci strains from canine otitis. Braz. J. Microbiol, v. 43, p. 371-4, 2012. Available from: <https://doi.org/10.1590/S1517838220120001000044>. Accessed: Apr. 10, 2018.

OLIVEIRA, L.C., et al. Antimicrobial sensitivity of bacteria from otitis externa in dogs. Arq. Bras. Med. Vet. e Zootec, v. 57, p. 405-408, 2005. Available from: <https://doi.org/10.1590/S010209352005000300021>. Accessed: Apr. 10, 2018.

PARK, J., et al. An investigation of exudative epidermitis (greasy pig disease) and antimicrobial resistance patterns of Staphylococcus hyicus and Staphylococcus aureus isolated from clinical cases. Can. Vet. J. = La Rev. Vet. Can, v. 54, p. 139-44, 2013. Available from: <http://dx.doi.org/10.1590/S0102-09352005000300021>. Accessed: Apr. 10, 2018.

ROHDE, H., et al. Structure, function and contribution of polysaccharide intercellular adhesin (PIA) to Staphylococcus 
epidermidis biofilm formation and pathogenesis of biomaterialassociated infections. Eur. J. Cell Biol. v.89, p.103-111, 2010 Available from: <https://doi.org/10.1016/J.EJCB.2009.10.005>. Accessed: Apr. 10, 2018.

ROHDE, H., et al. Correlation of Staphylococcus aureus icaADBC genotype and biofilm expression phenotype. J. Clin. Microbiol, v.39, p. 4595-6, 2001. Available from: <https://doi.org/10.1128/ JCM.39.12.4595-4596.2001>. Accessed: Apr. 10, 2018.

SHIRTLIFF, M.E., .et al. Molecular interactions in bBiofilms. Chem. Biol, v.9, p.859-871, 2002. Available from: $<$ https://doi org/10.1016/S1074-5521(02)00198-9>. Accessed: Apr. 10, 2018.

SOLATI, S.M., et al. Prevalence of virulence genes of biofilm producing strains of Staphylococcus epidermidis isolated from clinical samples in Iran. AMB Express, v.5, p.134, 2015. Available from: <https://doi. org/10.1186/s13568-015-0134-3>. Accessed: Apr. 10, 2018.

JUNCO, M.T., BARRASA, J.L. Identification and antimicrobial susceptibility of coagulase positive staphylococci isolated from healthy dogs and dogs suffering from otitis externa. J. Vet. Med. Ser. B, v.49, p.419-423, 2002. Available from: <https://doi.org/10. 1046/j.1439-0450.2002.00571.x>. Accessed: April 10, 2018.

VASUDEVAN, P., et al. Phenotypic and genotypic characterization of bovine mastitis isolates of Staphylococcus aureus for biofilm formation. Vet. Microbiol, v.92, p.179185, 2003. Available from: <https://doi.org/10.1016/S03781135(02)00360-7>. Accessed: Apr. 10, 2018.

ZMANTAR, T., et al. A microtiter plate assay for Staphylococcus aureus biofilm quantification at various $\mathrm{pH}$ levels and hydrogen peroxide supplementation. New Microbiol, v. 33, p.137-145, 2010. Available from: $<$ http://www.newmicrobiologica.org/PUB/ allegati_pdf/2010/2/137.pdf $>$. Accessed: Apr. 10, 2018.

ZOTTOLA, E.A., SASAHARA, K.C. Microbial biofilms in the food processing industry - Should they be a concern? Int. J. Food Microbiol, v.23, p.125-148, 1994. Available from: $<$ https://doi. org/10.1016/0168-1605(94)90047-7>. Accessed: Apr. 10, 2018. 